\title{
Professor, filósofo e crítico literário Benedito Nunes
}

Alfredo Bosi 
Tenho a honra e o prazer de saudá-lo neste encontro promovido em sua homenagem pela disciplina de Literatura Brasileira da Faculdade de Filosofia, Letras e Ciências Humanas da Universidade de São Paulo. Não é uma homenagem ao aniversariante, pois já fomos advertidos de que não é de seu agrado esse tipo de cerimônia, mas o justo reconhecimento de uma vida inteira de intelectual empenhado no conhecimento da Filosofia e da Literatura, empenho que Benedito Nunes continua demonstrando como talvez nenhum outro crítico literário brasileiro o tenha feito com tanto fôlego e profundidade.

Leitor de sua obra, desde os meados dos anos de 1960, quando da publicação da análise pioneira da escrita de Clarice Lispector, sempre admirei a vocação do pensador capaz não só de penetrar na palavra sibilina de Heidegger (de que Benedito Nunes é um dos mais atentos intérpretes em nossa língua), mas também de enfrentar os textos complexos de Clarice Lispector, João Cabral e Guimarães Rosa vistos pela ótica da fenomenologia existencial.

Foi uma escolha feliz, mas árdua. A crítica brasileira sempre encontrou dificuldade de penetrar filosoficamente na obra literária. Desde o século xıx, quando Sílvio Romero acumulou desastres sobre desastres na apreciação de nossos escritores, passando por José Veríssimo, leitor de melhor gosto, mas alheio a todo e qualquer sistema filosófico, a maior parte de nossos críticos oscilou entre o impressionismo psicologizante e o sociologismo redutor, ou entre essas posições e um formalismo extremado. As exceções contam-se nos dedos de uma só mão: Carpeaux, Tristão de Athayde, Álvaro Lins, Augusto Meyer, Antonio Candido e, naturalmente, todos os professores de Literatura aqui presentes e nossos amigos diletos.

No entanto, a visada ontológica e existencial, nem idealista, nem materialista, é iluminadora na medida em que, em vez de fechar-se no círculo de ferro dos condicionamentos locais ou flutuar em meio a especulações subjetivas, vai direto ao essencial, à aparição do fenômeno, à imagem da coisa, à força do evento, ao mistério mesmo do mundo e do Outro que a percepção cotidiana antes oculta do que revela. E aqui a citação de uma passagem de Heidegger sobre a arte, transcrita em um dos textos de Benedito Nunes, me parece obrigatória: "A arte é uma consagração e um

* Conferência proferida durante a homenagem ao prof. Benedito Nunes, no evento "Literatura e Filosofia: a Clave do Poético", realizado na Faculdade de Letras da Universidade de São Paulo, em 12 de novembro de 2009. Na ocasiāo, foi lançado o livro A clave do poético, de Benedito Nunes (apresentação e organização de Victor Sales Pinheiro; prefácio de Leyla Perrone-Moisés. São Paulo: Companhia das Letras, 2009). 
abrigo, por onde o real dispensa ao homem o seu brilho, até então escondido, para que numa tal claridade possa ver de maneira mais pura, e ouvir, mais distintamente, o que fala à sua essência".

Ao citar essas palavras, recomendo a todos que leiam atentamente os capítulos dos estudos heideggerianos em que Benedito Nunes aprofunda o sentido da "virada" do primeiro para o segundo Heidegger, que costuma ser assinalada pela publicação do célebre ensaio "Höelderlin e a essência da poesia".

Clarice, Rosa e Cabral, apesar das temáticas e paisagens diversas, têm o dom de suspender os nossos hábitos mentais e pôr-nos diretamente em contacto com a realidade estranha das coisas, dos homens, dos acontecimentos. Mas é preciso que um leitor perspicaz e independente como Benedito Nunes nos guie e nos oriente para o reconhecimento desse dom.

Ele o fez em seus livros de Filosofia e Crítica que nos alimentam há tantos anos. Há muito que se tornou leitura imprescindível o seu Passagem para o poético, que tive a sorte e a honra de acolher quando conselheiro editorial da Coleção Ensaios da Editora Ática. Há muito que O tempo na narrativa se converteu em bibliografia clássica insuperável nos cursos de Teoria Literária desta e de outras Faculdades de Letras. Há muito que não é possível dissociar a leitura de Clarice Lispector e de Guimarães Rosa dos ensaios luminosos de Benedito Nunes. E João Cabral: a máquina do poema é talvez a mais feliz intersecção de análise estrutural e interpretação fenomenológica.

Mas só agora, graças ao meritório trabalho de Victor Sales Pinheiro, pudemos ler ou reler alguns dos textos de Benedito Nunes esparsos em jornais, revistas ou obras coletivas às vezes de difícil acesso. Temos, nesta Clave do poético, o mapa da mina, o roteiro de um pensamento que habita os extremos da teoria pura e da leitura atenta de obras vistas na sua concretude e singularidade. Como disse Leyla Perrone- Moisés com graça e propriedade, no prefácio à obra, vemos aqui uma árvore amazônica deitando galhos por todos os lados. Podemos nos internar por essa ramagem viçosa e pujante que surpresas não vão faltar. $\mathrm{O}$ leitor ficará no mínimo boquiaberto ao encontrar neste livro nada menos do que uma entrevista que Benedito Nunes concedeu a ninguém menos do que Clarice Lispector em torno de problemas de crítica e de literatura brasileira. Clarice pergunta e Benedito responde. Não é o caso de ser tomado de santa inveja? E reconhecerá também uma atitude corajosa e generosa no seu deter-se em autores que dificilmente ultrapassariam suas fronteiras regionais se não os trouxesse ao primeiro plano da crítica este leitor sem fronteiras, que é Benedito Nunes; pois o mesmo ensaísta de horizontes universais 
que discorre com toda a segurança sobre Eliot e Rilke nos vai revelar a força da prosa ficcional de seu conterrâneo Dalcídio Jurandir, tão pouco lido aqui no Sul. E dedica um denso texto a outro paraense, o poeta Max Martins, que, confesso, só vim a conhecer faz pouco tempo quando pedi a Benedito Nunes a sua colaboração em um dossiê sobre a Amazônia editado por Estudos Avançados. Sem falar na sua exegese fascinante da poesia de Mário Faustino que, como sabemos, só pôde ser logo conhecido e admirado porque transpôs cedo os confins da sua província. Mas por tão curto tempo... É por tudo isso e muito mais que o homenageamos neste momento e neste lugar, onde não estamos para falar de Benedito Nunes, mas para ouvi-lo e dele tomar lições de pensamento. Agora, estamos à sua escuta.

Alfredo Bosi é professor titular na Universidade de São Paulo, autor de Ideologia e contraideologia (Companhia das Letras, 2010); Brás Cubas em três versões (Companhia das Letras, 2006); Literatura e resistência (Companhia das Letras, 2002); Machado de Assis: o enigma do olhar (Ática, 1999); Dialética da colonização (Companhia das Letras, 1991); entre outros. 